\title{
The Involvement of Informal Sector Society in English Habituation at Kampung Inggris Pare Kediri
}

\author{
Wiwin Yulianingsih, Supriyono, Ach. Rasyad, Umi Dayati \\ Universitas Negeri Malang \\ Malang, Indonesia \\ wiwinyulianingsih@unesa.ac.id
}

\begin{abstract}
This research was aimed to describe and analyze the workers' participation in the informal sector in the habituation for learning English at the Kampung Inggris, Pare Kediri. The research approach is a qualitative-descriptive approach by collecting the interview data, observation, and documentation. The result of this research is that the participation or the workers' in the informal sector has run smoothly and positive, as we can see from 1). The involvement of the workers in the habituation for learning English in a camp and guided by English tutors who helped them to familiarize the communication in English as a Foreign Language correctly and appropriately. The activities run in the evening until the night before 9 p.m. 2). The involvement or the participation of ojek drivers and food sellers in the habituation and implementation of communication in English daily could be done maximally, like when they used to communicate in English to the course participants at Mahesa, BEC, and Rhima. 3). The involvement of food seller in the English habituation course program could be done very well and run smoothly as seen when they adapt and practically communicate with the participants in English.
\end{abstract}

Keywords—informal sector; English habit; society

\section{INTRODUCTION}

Education has a function as an individual helper in order to overcome the problems of life that include the application of information and technology owned to increase the quality of life (Faure: 1972). Roger A stated, "Education was also been to be the potential savior." Education as a process that takes place throughout the life of the individual and by that fact, education will always be a solution for a human to face their complex problems in order to increase their quality of life in accordance with its objectives (Rogers: 1969).

In line with the world's progress, English as the Foreign language becomes very important to learn. As a global language, English has evolved from the beginning of 1950 which is not spread and mean well in some part of the countries but has progressed widely in the beginning of 1970 until 1980 which known as "English Era". Later in the early of 2000, the new perception about English as a universal language appeared, before it is only minimally used has successfully made a famous writer stated: "English is the global language" (crystal in Lily Fernandes and Nora Hadi Q
Alsaeed, 2014:126). McKay (in Ning, 2017:22) continued, "The interest for learning English has increased significantly, and make it as an International Language by many researchers."

The appearance of ASEAN Economic Market which has been run for about 2 years should be followed by English competencies such as writing, listening, and the other skills or competencies started from educational basic institution (elementary school), college students, employees, and every society whose have direct or indirect connections with industrial, education, or service sectors (Wu: 1991).

That is the reason why education is considered as a continuous process that aimed to enhance society quality of life, including children until adults (Bentley: 2012). It also includes some reason why the government tries to evaluate and enhance the English competencies through the teachers and lecturers in our country. The assumption can be logically illustrated as stated, "Imagine if we have high-quality teachers in our school, then he/she can foster the competencies of his/her students up to 10 or 15 in amount. If that so, what if we have 1000 teachers or more in our country with the same or mostly same quality and competencies in English? That would be fantastic".

The English learning process happens in non-formal and informal sectors through courses programs, private lessons, etc. This learning process could be accessed by every society in the cities or country (Werquin: 2010). Not only accessible, each city or country in Indonesia actually has English language institutional courses as a service for learners, workers, etc. The problem is they often think that only one English language institutional courses which are the best in Indonesia, located at Pelem Kampung Inggris, Pare Kediri. In addition, the English programs in Kampung Inggris Pare Kediri offers several services and charges according to the variety of programs.

Kampung Inggris is a small village that famous for their interesting phenomenon that involves every civilian to run non-formal education programs such as English courses, etc. This village is better known by the term or epithet "Kampung Inggris" alongside Anyelir street, Brawijaya street and 
Kemuning street at Tulungrejo village and Pelem village, Pare district, Kediri regency, east java. The Kampung Inggris only has an area of approximately $47.21 \mathrm{~km} 2$. With an area like that, there are approximately 100 of English courses in that village and make it as an educative destination which can attract local and international tourist where they can learn English, learn and enjoy their culture, etc.

An English course is a form of an educational institution which serves learners necessity in order to learn and master the English competencies such as reading, writing, speaking, and listening. The courses participants can learn English competencies with their tutor in the class or practically learn English as a communication with the society around there.

The society supports and contributes actively to courses with the participants and tutors. This condition was aimed to establish a habituation for every learners or courses participant during their study and training at the English village. In addition, the participants can practice using their new knowledge, especially their soft skill with the society and their neighborhood in order to get new experiences in every sector such as the informal workers (owner of the cafes, siomay and batagor seller, ojek drivers, etc.)

At least, there are 2 villages whose society actively support and contribute to the success of the program; Tulungrejo village and Singgahan village, Pare - Kediri. This participation will also bring positive impact in the future if they can continuously run the programs and actively increase their ability in the future. The society independence will contribute to their habituation to manage local development programs (Soetomo, 2013:10).

As the individuals and social living creature, social participation has a big contribution to influence planning process, actuating process, and controlling/ monitoring their policies that have direct or indirect affections to their movement. As explained by Conyers (1991) in Turindra (2009), there are some important points in the social participation, for example: first, social participation can be used to obtain information about social conditions, needs, and manners. If the participation is low or even nothing at all, then the development will not succeed. Second, a statement connects between society participation in planning, actuating, and monitoring with the programs succeeded. In short, they will trust the programs if they also being involved within. Third, we cannot deny that it is their rights to involve in the process of projecting the programs which aimed for their interest and their prosperity. These points are harmonizing with the concept of man-centered development; development projects which aimed for their betterment.

Habituation is a "mental and cognitive" structure that people can socialize with. When they make a contact with the social environment, they cannot fall apart from social interaction and space. In order to fulfill a social prerequisite, a person must have capital through social interaction and space with each of the society around them. According to Bourdieu, capital consists of economic side, social side, cultural side, and symbolic (Ritzer \& Goodman 2012:581).
The continuity of social participation on non-formal education habituation especially for informal workers such as but not limited to siomay sellers, camp owners, and ojek drivers has not been shown yet their participation around Kampung Inggris in Pare Kediri due to their low integration and acceptance from the institutional. They only act as a figurative actor during the programs and unfortunately, they do not receive any potential training from the language institutional in order to boost participant performances informally. This phenomenon is very interesting to be observed and create a new model as a pioneering along with the English village programs. If the research smoothly conducted, then it will open several possibilities to form a complex and integrated English society in Indonesia.

That is also the reason why the research team wants to conduct the observation and research with a title "The Involvement of Informal Sector Society in English Habituation at Kampung Inggris Pare Kediri". The research focus is to learn informal sector workers in the habituation of English course at Kampung Inggris Pare - Kediri.

\section{METHOD}

The research was conducted using a qualitative approach, which aimed to understand the phenomenon experienced by the subjects (Malterud: 2001). According to Bogdan and Taylor (in Moleong, 2005:135), they define qualitative approach as a research procedure which resulted in a descriptive data in written or spoken form taken and observed from subjects behavior. In order to find scientific facts and data, the researchers agreed to apply qualitative descriptive methods because descriptive research gave indications, facts, or events accurately and systematically about population characters or particular places (Polkinghorne: 1989).

The main subjects of this research are informal workers divided into 3 groups consist of: Owners of the camp at English Village (Camp Firdaus House), food sellers and ojek drivers, Rhima course and Mahesa Institute. Data analysis technique used in this research is an analysis of theory testament since the data is narrative. Data analysis technique used in this research can be described as mentioned: (1). Data collection, 2). Data reduction, 3). Data display, 4). Data verification. Data validity examination technique is very needed in order to measure whether the data are valid or not; to set data validity, examining data validity needed. The implementation of inquiry technique is based on several criteria such as 1). Credibility, 2). Transferability, 3). Dependability, 4). Confirmability.

\section{RESULTS AND DISCUSSION}

Data analysis was conducted from data collecting through observation, interview, and documentation. Data tabulation in this research is how the process of social participation especially informal workers on the habituation process in Pare, Kediri.

The appearance of the oldest and the most famous English course institution is Basic English Course (BEC) which established in 1977 by Muhammad Kalend Oseng. From this course, many people from many places in Indonesia has 
successfully graduated every year, including the participants from Pare, Kediri and several alumni of BEC started to set up the idea of establishing another English courses such as HEC 1, HEC 2, Rhima course, Mahesa Institute, Daffodil, etc. While there are also several new English courses established about 5 years ago such as Peace, FEC, Cambridge, Britain, Global, etc.

Moreover, this kind of village has become the biggest English learning center in Indonesia. With numerous English courses in Indonesia, it is possible for a citizen in many cities communicating with other people using English as a product of English courses in Indonesia. So far, social participation in the informal sector has been increased significantly, as for the example are ojek drivers and siomay-batagor sellers in front of BEC.

In the participation development strategy, there are several rational considerations that underlie it (Mikkelsen, 1999:66). Normatively, the assumption underlying this condition is that local society should be given a project and constructive program which they decide by themselves. This normative assumption based on a deductive assumption which emphasizes on a general fact that they are the one who knows their own problems and needs; therefore, they know their position including their rights and their abilities to express what is inside their mind and their own will to decide what to do. Therefore, if local programs and projects took and conducted by the society around there then that will become more relevant and accurately touch their fundamental problem and also they could fulfill their own needs accurately.

The same as experienced by the society of English village in Pare, Kediri. Their involvement is caused by the advantage they feel from the appearance of English courses at their village, and they positively respond to this opportunity by modifying or build their house as boarding houses/ camp, food stalls, café, shops/ stores, bookstores, etc. After that their involvement in the English habituation process is using English as their communication media with everyone there, including with the participants of English courses at Pare, Kediri.

The connection between the society (camp owners), food sellers, and ojek drivers as the informal workers describe the result of social participation, especially for informal workers.

1. Camp Firdaus House, located on Brawijaya street number 88 a Tulungrejo Village, owned by the original civilian from Pare although the person can't continue to operate the camp's program because of his illness. Thus, he trusts the camp's operation to his son and his daughter-in-law, Rois and Nur Vaizah, who aged 30 years old. They learned English skills and competencies at a course located in Tuban and continue their learning in this English village. Not only operate their camp, both of them also become the structure of other 2 English course at Kampung Inggris Pare Kediri.
In order to support the program in English village Pare, Kediri, a guide or tutor has been placed in every camp to support and guide them through the habituation process. Every guide or tutor in this English village has been trained and prepared with English skills and competencies between 6-9 months which is also being a part of social participation. Not only the guides or tutors, the owners of the camp also participate the habituation process through everyday activities continuously. There is some differentiation between each service offered to the participants especially the cost. For the participant who prefers boarding house rather than camp will have to pay cheaper cost than that of camp but they will not receive any guide or tutor so they only learn English in a general way, communicate and common material. On the other side, a participant who prefers a camp will have to pay higher but they will be guided by a tutor between 4 p.m. to 6 p.m. and continue at 7:30 p.m. to 8:45 p.m. every day, a material class, socialization, etc. But the general purpose of this program no matter the service they take is same, to master English competencies through habituation process.

Society Involvement on creating the program's formulation has made them act not only as a consumer of their products or services but also as the producer because of their participation on formulating the programs for English village itself. Therefore, they feel as if the programs are theirs after being participated from the beginning and grow a good response to succeed every aspect of the English course programs in English village, Pare, Kediri. By that reason, society participation in succeeding the programs will be formed because of their consciousness and their determination, and not only because of any mobilization from external parties. (Soetomo, 2013:10)

2. Ojek drivers or Pedicab drivers

The next is the pedicab driver/ motorcycle who can take more passengers with a minibus belonging to his brother, as well as keeping the shop owned by his wife, the location of shops is also very strategic, in front of English course institutions (Mahesa Institute), his name is Mr. Nur, 56 years old, very fluent in English. The involvement of Mr. Nur in the habituation process through English course is very visible in everyday activities, while he is serving the consumer of his shop, he used to interact using English language, so it was seen on board the next stall writing: If you want to go, To The Railway/Train Station To The Bus Station, To The Tourism Kediri, Come Join Me, Uncle Nur 085235513768. 085649314772.

The involvement of Mr. Nur in the presence of English language courses sustainability of the non-formal education activities, including the time when he stalls his bentor and drive the participant to the course participants train station, bus terminal or escort them 
around the sights in Kediri. Mr. Nur explanation indicates that public participation on habituation nonformal education is very remarkable, as evidenced by the results of interviews and observations conducted by researchers, there are course participants from Mahesa, three people came to Mr. Nur shop, and he serves and communicates with them in English from the beginning to the end.

Uncle Nur, said that already practicing communication in English for 8 years, and gaining proficiency in English from learning to hear and converse directly with children who are learned at English language courses in Mahesa Institute and its surroundings, even had time to get English language training in brief by Mr. Kalend, founder and pioneer of BEC and English Village.

Such an attitude should also be reflected in the effort to improve the quality of human resources. It cannot be denied, one way is quite important in improving the quality of the human family through educational resources. In this case the efforts to develop human resources to reach a wider dimension than just the human form of professional and skilled according to the system needs to be able to contribute in the development process, but emphasized the importance of human empowerment, including the ability to actualize all of its potential as a human being (Tjokrowinoto, 1996: 29).

A further implication of this view appears from the attempts to formulate a definition of development participation. Community participation in development is community involvement in the process that is based on the awareness and terminated cannot be called as participation in general and more accurately described as the mobilization of the Development. The concept reflects the mobilization of human and people as objects rather than subjects (Soetomo, 2013: 13).

3. Food sellers

It can be seen at vending carts siomay batagor, there is a writing "No Bravery No victory, Tri Never Never Know: Let's Practice English with Me". The posts in the cart show their active community involvement in the process of learning English habituation. Mr. Totok, 44 years old said that while serving the course participants, he used to communicate using English to the siomay and batagor buyers. He develops the English language because it can be the training of $\mathrm{Mr}$. Kalend, owner and founder of the BEC, the oldest and longest as one of the English language institution in Pare. He said that familiarize themselves with the participants to always use English is important in order to improve their English ability, for both the sellers (society) and the learners (participants). Mr. Totok sees the importance of getting used to practice English with the participants of the course in order to improve their ability through English language courses with the purpose of habituating them.

Mr. Totok's English skills, is the participation form of English language training for informal sector workers held at the BEC by Mr. Kalend once a week every Friday evening, 19:00 to 21:00 hours.

Sudjana (2001) explains that public participation in the activities of the learning process is also influenced by learning strategies. In the implementation of nonformal education that implements participatory learning strategies have this following principle: 1) based on the needs of learning (learning needs based), which needs to learn due to the will or the needs of the community;

2) The goal-oriented of learning activities (learning goals and objectives oriented) that are planned and executed to achieve the learning objectives are predetermined; 3 ) centered on the students (participant centered) that learning is based on and adapted to the background of the lives of learners; 4) departing from experiential learning (experimental learning) is learning activities organized and conducted by departing from the things that have been controlled by the learning.

\section{CONCLUSION}

Participation or civic engagement/ social participation in the habituation process of non-formal education through English language courses in the English village of Pare went very well, as object and subject communities in the development process and the presence of the English village Pare. Citizen of the informal sector workers feel the benefits of the presence of the institution in the English village. Starting from setting up camp that is supported by the facility to learn English in a residence, as food among students of their own age who are courses up to the ojek drivers. Among informal sector workers, they join to learn English so they are able to communicate with the learners in the English village Pare. Informal sector workers can apply it in their daily lives to communicate in English, when at boarding/ camp (the residence), the needs of transportation transactions and foodservice sales. Society involvement in the process of habituation English lasts for course participants in the English village environment, this is applied to one another, for the participants as well as informal sector workers because of habituation in English is necessary in order to improve their English.

\section{REFERENCES}

[1] J Lexy, Moleong. 2006. Metode Penelitian Kualitatif Edisi Re-visi. Bandung: PT Rosda Karya.

[2] Samani, Muchlas, Hariyanto. 2011. Konsep dan Model Pen-didikan Karakter. Bandung Remaja Rosdakarya.

[3] Sudjana. 2001. Pendidikan nonformal, Wawasan, Sejarah, Perkembangan, Falsafah, Teori Pendukung, Asaz. Bandung: Falah Production.

[4] Sudjana, Nana \& Rivai, Ahmad. 2007. Teknologi Pengajaran. Bandung: Sinar Baru Algensindo.

[5] Turindra, Azis. 2009. Pengertian Partisipasi. Online. Tersedia: http://turindraatp.blogspot.com/2009/06/pengertian-partisipasi.html. 
[6] Ritzer \& Goodman. Teori Sosiologi Klasik - Post Modern Edi-si Terbaru (Trans: Nurhadi). Yogyakarta: Kreasi Wacana. 2012.

[7] Setiawati, Ning. 2016. 4 skills penting saat belajar dalam baha-sa Inggris yang wajib kita ketahui. (online). (http://www.ilmubahasainggris.com/ diakses 15 Februari 2017.

[8] Soetomo, 2013. Strategi-strategi Pembangunan Masyarakat. Jogjakarta. Pustaka Pelajar.

[9] Mikkelsen, Britha, 1999, Metode Penelitian Partisipatoris dan Upayaupya pemberdayaan, yayasan Obor Indonesia, Ja-karta.

[10] Tjokrowinoto, Moeljarto, 1996. Pembangunan, Dilema dan Tantangan, Pustaka Pelajar. Yogjakarta.

[11] Rogers, C. R. (1969). Freedom to learn: A view of what education might become. Columbus, $\mathrm{OH}$ : Charles E. Merrill.
[12] Wu, F. (1991). The ASEAN Economies in the 1990s and Singapore9s Regional Role. California Management Review, 34(1), 103-114.

[13] Werquin, P. (2010). Recognition of non-formal and informal learning: Country practices. Organisation de coopération et de développement économiques OCDE. Paris. Disonible en.

[14] Bentley, T. (2012). Learning beyond the classroom: Education for a changing world. Routledge.

[15] Polkinghorne, D. E. (1989). Phenomenological research methods. Existential-phenomenological perspectives in psychology: Exploring the breadth of human experience, 41-60.

[16] Faure, E. (1972). Learning to be: The world of education today and tomorrow. Unesco.

[17] Malterud, K. (2001). Qualitative research: standards, challenges, and guidelines. The lancet, 358(9280), 483-488. 